\title{
Shewanella canadensis sp. nov. and Shewanella atlantica sp. nov., manganese dioxide- and hexahydro-1,3,5-trinitro-1,3,5-triazine-reducing, psychrophilic marine bacteria
}

\author{
Correspondence \\ Jian-Shen Zhao \\ jian-shen.zhao@cnrc-nrc.gc.ca \\ Jalal Hawari \\ jalal.hawari@nrc.ca
}

\author{
Jian-Shen Zhao, ${ }^{1}$ Dominic Manno, ${ }^{1}$ Sonia Thiboutot, $^{2}$ Guy Ampleman ${ }^{2}$ \\ and Jalal Hawari ${ }^{1}$
${ }^{1}$ Biotechnology Research Institute, National Research Council of Canada, 6100 Royalmount Ave, Montreal, Quebec H4P 2R2, Canada
${ }^{2}$ Defence Research and Development Canada, 2459 Pie IX Boulevard, Valcartier, Quebec G3J 1X5, Canada

Two strains belonging to the genus Shewanella, HAW-EB2 ${ }^{\top}$ and $\mathrm{HAW}-\mathrm{EB} 5^{\top}$, were isolated previously from marine sediment sampled from the Atlantic Ocean, near Halifax harbour in Canada, for their potential to degrade explosive hexahydro-1,3,5-trinitro-1,3,5-triazine (RDX). In the present study, strains $\mathrm{HAW}-\mathrm{EB} 2^{\top}$ and $\mathrm{HAW}-\mathrm{EB}^{\top}{ }^{\top}$ were found to display high $16 \mathrm{~S}$ rRNA gene sequence similarity (90-99.5\%) to species of Shewanella, but their gyrB sequences were significantly different from each other and from species of Shewanella (79-87.6\%). Furthermore, DNA-DNA hybridization showed that the genomic DNA of the two strains was only $22 \%$ related and showed less than $41 \%$ relatedness to closely related species of Shewanella. In comparison to other species of Shewanella, strains HAW-EB2 ${ }^{\top}$ and $\mathrm{HAW}^{-E B} 5^{\top}$ were also unique in some phenotypic properties such as activities of $\beta$-galactosidase and tyrosine arylamidase and the ability to metabolize certain organic acids and sugars. Both strains $\mathrm{HAW}-\mathrm{EB} 2^{\top}$ and $\mathrm{HAW}-\mathrm{EB}^{\top}{ }^{\top}$ utilize malate, valerate, peptone and yeast extract as sole carbon and energy sources. The major membrane fatty acids of the two strains were $C_{14: 0}$, iso- $C_{15: 0}$, $\mathrm{C}_{16: 0}, \mathrm{C}_{16: 1} \omega 7, \mathrm{C}_{18: 1} \omega 7$ and $\mathrm{C}_{20: 5} \omega 3$ and their major quinones were Q-7, Q-8 and MK-7. On the basis of these results, strain HAW-EB2 ${ }^{\top}\left(=\right.$ NCIMB $\left.14238^{\top}={\left.\text { CCUG } 54553^{\top}\right)}\right)$ is proposed as the type strain of Shewanella canadensis sp. nov. and strain HAW-EB5 ${ }^{\top}$ $\left(=\right.$ NCIMB $14239^{\top}=$ CCUG $\left.54554^{\top}\right)$ is proposed as the type strain of Shewanella atlantica sp. nov.
Members of the genus Shewanella are Gram-negative, oxidase-positive, rod-shaped, aquatic bacteria whose genomic DNA contains 38-54 mol\% G+C (Bowman, 2005). At the time of writing, there are 38 species of Shewanella with validly published names (http://www.bacterio.cict.fr/ s/shewanella.html), mostly isolated from marine environments, with a few isolated from freshwater sediment, industrial wastewater, clinical specimen and spoiled foods.

Abbreviations: RDX, hexahydro-1,3,5-trinitro-1,3,5-triazine; TMAO, trimethylamine $\mathrm{N}$-oxide.

The GenBank/EMBL/DDBJ accession numbers for the 16S rRNA gene sequences of strains HAW-EB2 ${ }^{\top}$ and $\mathrm{HAW}^{-E B 5^{\top}}$ are $\mathrm{AY} 579749$ and AY579752 and those for the gyrB gene sequences of strains HAW$\mathrm{EB}^{\top}{ }^{\top}$ and $\mathrm{HAW}-\mathrm{EB}^{\top}{ }^{\top}$ are $\mathrm{AY} 842129$ and $\mathrm{AY} 842132$.

A comparison of the fatty acid compositions of strains $\mathrm{HAW}-\mathrm{EB} 2^{\top}$ and $\mathrm{HAW}-\mathrm{EB} 5^{\top}$ and related species is available as supplementary material with the online version of this paper.
Members of Shewanella can grow aerobically or anaerobically by reducing alternative electron acceptors such as trimethylamine $\mathrm{N}$-oxide (TMAO) and nitrate (Bowman, 2005). Species of Shewanella also require or tolerate $\mathrm{NaCl}$ (1-4\%) and low temperatures for growth (Zhao et al., 2005). Some species isolated from cold and deep-sea environments, such as Shewanella hanedai, S. gelidimarina, $S$. violacea and S. benthica, are known for production of polyunsaturated fatty acids (Kato \& Nogi, 2001; Russell \& Nichols, 1999; Bowman et al., 1997). Species such as Shewanella oneidensis and S. putrefaciens have been reported to be able to reduce heavy-metal oxides (Myers \& Nealson, 1988; Roh et al., 2006) and chlorinated pollutants (Petrovskis et al., 1994) and for their potential to generate electricity (Ringeisen et al., 2006; Park \& Zeikus, 2002).

Previously, we reported the isolation of several psychrophilic strains of Shewanella, including strains HAW$\mathrm{EB}^{\mathrm{T}}$ and $\mathrm{HAW}-\mathrm{EB5}^{\mathrm{T}}$, for their ability to degrade 
hexahydro-1,3,5-trinitro-1,3,5-triazine (RDX) in sediment from an undersea unexploded ordnance dumping site at Emerald Basin, in the Atlantic Ocean, that is $215 \mathrm{~m}$ deep and 50 nautical miles $(93 \mathrm{~km})$ from Halifax harbour, Canada (Zhao et al., 2004a, b). In the present study, we provide genetic, chemotaxonomic and phenotypic evidence to propose each of the isolates as the type strain of a novel species of Shewanella.

As described previously, strains HAW-EB2 ${ }^{\mathrm{T}}$ and HAW$\mathrm{EB}^{\mathrm{T}}$ are Gram-negative, psychrophilic bacteria with an optimal temperature of $10{ }^{\circ} \mathrm{C}$ for growth (Zhao et al., 2004a). The two strains grew well in marine medium 2216 (liquid or agar; Becton Dickinson) or Brewer anaerobic agar (Becton Dickinson) supplemented with either sea salts (Sigma; $4 \%$ ) or $2 \% \mathrm{NaCl}$. The biomass had a pinkish colour, typical of Shewanella (Bowman, 2005; Venkateswaran et al., 1999).

Cells of strain HAW-EB2 ${ }^{\mathrm{T}}$ and HAW-EB5 ${ }^{\mathrm{T}}$ harvested after 3 days of aerobic growth in marine broth 2216 were used for transmission (TEM; Hitachi H7500) and scanning (SEM; Hitachi S3000N) electron micrographic imaging analyses under previously described experimental conditions (Zhao et al., 2006). Both strains showed cellular morphology similar to other members of Shewanella: straight or slightly curved rods $(1-5 \mu \mathrm{m}$ long and $0.55-$ $0.7 \mu \mathrm{m}$ in diameter) with a single flagellum in a polar position (Fig. 1).

To determine the phylogenetic affiliation of the two bacteria, genomic DNA (1-5 mg) was purified using Marmur's method (Johnson, 1994) from the present isolates and Shewanella woodyi ATCC $51908^{\mathrm{T}}$ and S. hanedai ATCC $33224^{\mathrm{T}}$, purchased from the American Type Culture Collection. Genes were amplified using primers generated in this study by the Genetool software (Biotools Inc.) and known sequences published in GenBank, and the experiments were conducted using standard protocols (Sambrook \& Russell, 2001). The forward and reverse primers used to amplify $16 \mathrm{~S}$ rRNA genes were $5^{\prime}$ AAGCCACGGCTAACTACG and 5'-GTGTGTACAAGNCCCGGGAA, respectively. The forward and reverse primers used to amplify gyrB (encoding the $\beta$ subunit of DNA topoisomerase II) were 5'-MGGYGGTCTGCACGGCGT and 5'-GTGGCAGAATCGCTTGGT, respectively. The resulting $16 \mathrm{~S}$ rRNA (1282-1295 bases) and gyrB (9391013 bases) gene PCR products were subsequently sequenced and compared with published sequences using BLAST and aligned with those of closely related species using CLUSTAL_X (1.81). The neighbour-joining method (Saitou \& Nei, 1987) included in the MEGA3 package (Kumar et al., 2004), based on pairwise nucleotide distances from Kimura's two-parameter method (complete deletion) (Kimura, 1980), was used to build phylogenetic trees (Figs 2 and 3). The number of bootstrap repetitions was 4000 .

Strains HAW-EB2 ${ }^{\mathrm{T}}$ and HAW-EB5 ${ }^{\mathrm{T}}$ were $98.9 \%$ similar to each other in their 16S rRNA gene sequences. Phylogenetic analyses based on 16S rRNA gene sequences showed that both strains were members of Shewanella, 90-99.5\% similar to members of all 38 recognized species of the genus (Fig. 2). The $16 \mathrm{~S}$ rRNA genes of strain HAW-EB2 ${ }^{\mathrm{T}}$ and strain HAW-EB5 ${ }^{\mathrm{T}}$ formed a solid cluster (with a bootstrap value of $82 \%$ ) with three intermediate-sea species of Shewanella (95.7-99.5\% similar), including two bioluminescent isolates (S. woodyi ATCC $51908^{\mathrm{T}}$, S. hanedai ATCC $33224^{\mathrm{T}}$ ) and another Halifax isolate, Shewanella sediminis DSM $17055^{\mathrm{T}}$ (Fig. 2). The 16S rRNA genes of both strain $\mathrm{HAW}-\mathrm{EB} 2^{\mathrm{T}}$ and strain $\mathrm{HAW}-\mathrm{EB} 5^{\mathrm{T}}$ displayed the highest similarity to $S$. sediminis DSM $17055^{\mathrm{T}}$ (HAW$\mathrm{EB}^{\mathrm{T}}, 99.5 \%$; HAW-EB5 ${ }^{\mathrm{T}}, 98.6 \%$ ), a bacterium that was previously isolated from this site (Zhao et al., 2005). Two barophilic and deep-sea species of Shewanella, S. benthica and S. violacea, also showed 96.8-97.3\% 16S rRNA gene sequence similarity to strains $\mathrm{HAW}-\mathrm{EB} 2^{\mathrm{T}}$ and HAW-EB5 ${ }^{\mathrm{T}}$. However, these two species, isolated from the intestine of a sea animal and sediment of deep Atlantic or Pacific Trenches (Deming et al., 1984; Nogi et al., 1998), appeared
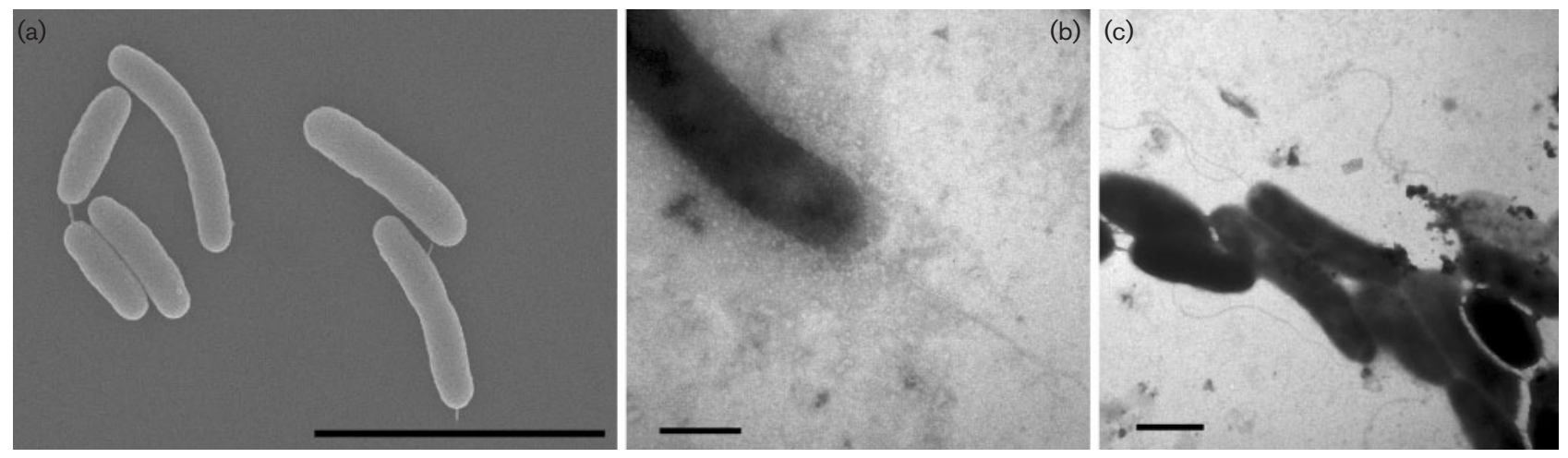

Fig. 1. (a) Scanning electron micrograph of cells of strain HAW-EB2 ${ }^{\top}$. (b, c) Transmission electron micrographs of negatively stained cells of strain HAW-EB2 ${ }^{\top}$ (b) and strain $\mathrm{HAW}^{-E B} 5^{\top}$ (c) showing a single polar flagellum. Bars, $5 \mu \mathrm{m}(\mathrm{a}), 0.5 \mu \mathrm{m}(\mathrm{b})$ and $1.0 \mu \mathrm{m}$ (c). 


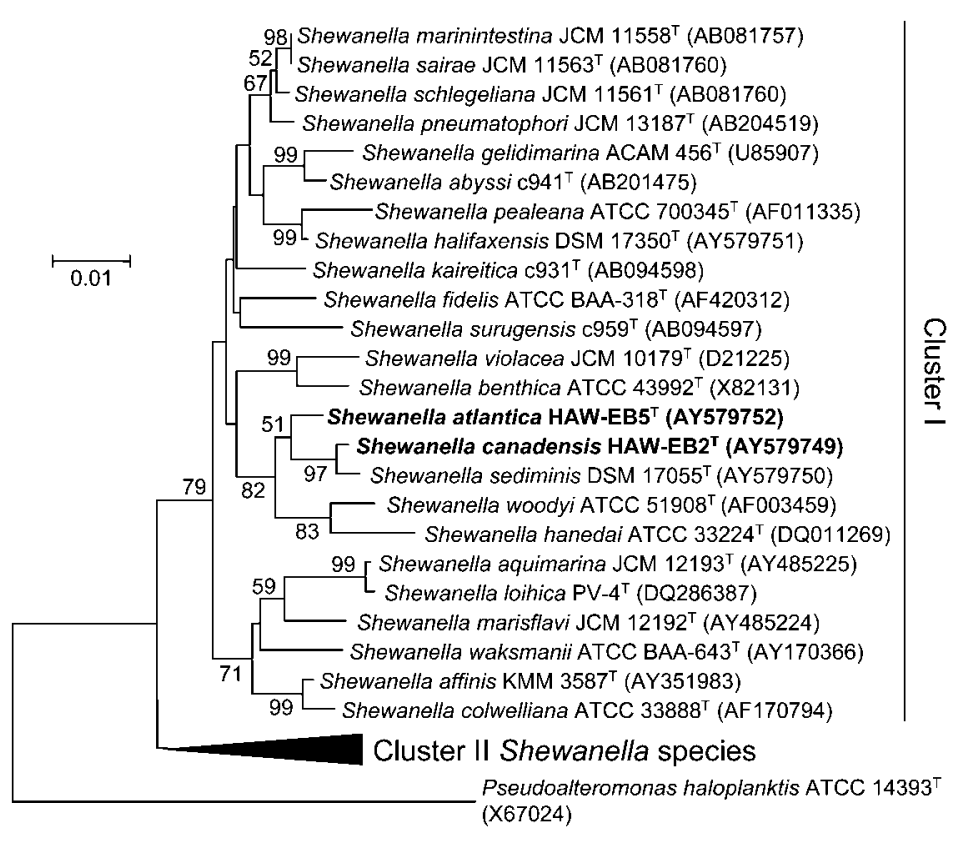

Fig. 2. Phylogenetic tree based on $16 \mathrm{~S}$ rRNA gene sequences of strains $\mathrm{HAW}-\mathrm{EB} 2^{\top}$ and HAW-EB5 ${ }^{\top}$ and type strains of Shewanella species. The tree was generated based on pairwise nucleotide distances as described in the text. Bar, 1 substitution per 100 nucleotide positions. Numbers beside nodes are statistical bootstrap values (values lower than $50 \%$ are not shown). Cluster II includes sequences of Shewanella amazonensis ATCC 700329 ${ }^{\top}$ (GenBank accession no. AF005248), $S$. algae IAM $14159^{\top}$ (U91546), S. pacifica KMM $3597^{\top} \quad$ (AF500075), $S$. japonica LMG 19691 $^{\top} \quad(\mathrm{AF} 145921), \quad$ S. olleyana ACAM $644^{\top}$ (AF295592), S. livingstonensis LMG $19866^{\top}$ (AJ300834), S. frigidimarina ACAM 591 ${ }^{\top}$ (U85903), S. denitrificans DSM $15013^{\top} \quad$ (AJ311964), S. gaetbuli JCM $11814^{\top} \quad$ (AY190533), $S$. profunda JCM $12080^{\top}$ (AY445591), S. putrefaciens ATCC $8071^{\top}$ (X82133), S. oneidensis ATCC $700329^{\top} \quad(A F 005251), \quad S$. baltica DSM 9439 ${ }^{\top}$ (AJ000214), S. morhuae U1417 ${ }^{\top}$ (AB205576), S. hafniensis $\mathrm{P}^{2} 10^{\top}$ (AB205566) and $S$. decolorationis IAM $15094^{\top}$ (AJ609571). to belong to a lineage different from the one including the three intermediate-sea species S. woodyi, S. hanedai and S. sediminis, as shown in Fig. 2.

Strains HAW-EB2 ${ }^{\mathrm{T}}$ and $\mathrm{HAW}-\mathrm{EB} 5^{\mathrm{T}}$ were $87.6 \%$ similar in the sequences of their $g y r B$ genes. This similarity value is lower than the $90 \%$ species cut-off value proposed for Shewanella by Venkateswaran et al. (1999), thus the two strains appeared to belong to different species of Shewanella. The gyrB gene sequences of strains $\mathrm{HAW}-\mathrm{EB} 2^{\mathrm{T}}$ and HAW-EB5 $5^{\mathrm{T}}$ were also found to be less than $90 \%$ similar (79-86.5\%) to known species of Shewanella including $S$. woodyi, S. hanedai, S. sediminis, S. benthica and S. violacea (Fig. 3; Table 1). Therefore, strain HAW-EB2 ${ }^{\mathrm{T}}$ and HAW$\mathrm{EB}^{\mathrm{T}}$ likely represent novel species of Shewanella.

The $\mathrm{G}+\mathrm{C}$ content of genomic DNA of strains HAW-EB2 ${ }^{\mathrm{T}}$ and $\mathrm{HAW}-\mathrm{EB} 5^{\mathrm{T}}$ was determined from the $A_{269} / A_{280}$ ratio at pH 3.0 as described by Johnson (1985a) and was found to be 46.4 and $46.6 \mathrm{~mol} \%$, respectively, consistent with reported values $(38-54 \mathrm{~mol} \%)$ for other species of Shewanella (Bowman, 2005).

To determine the relatedness between total genomic DNA of strains $\mathrm{HAW}-\mathrm{EB} 2^{\mathrm{T}}$ and $\mathrm{HAW}-\mathrm{EB} 5^{\mathrm{T}}$ and related species of Shewanella, we conducted genomic DNA-DNA hybridization tests using the spectrophotometric method as described by Johnson (1985b) and Bowman et al. (1998). As shown in Table 1, genomic DNA of strains HAW-EB2 ${ }^{\mathrm{T}}$ and $\mathrm{HAW}-\mathrm{EB} 5^{\mathrm{T}}$ showed only $22 \%(n=3)$ relatedness to each other and less than $41 \%(n=3)$ relatedness to the type strains of three closely related species of Shewanella, $S$. woodyi, S. hanedai and S. sediminis. Since the relatedness values are below the $70 \%$ species cut-off value recommended for bacteria (Wayne et al., 1987; Stackebrandt \& Goebel, 1994), strains HAW-EB2 ${ }^{\mathrm{T}}$ and HAW-EB5 ${ }^{\mathrm{T}}$ likely represent two novel species of Shewanella.

To provide chemotaxonomic evidence for the affiliation of the two strains to Shewanella, we characterized their quinone content as described by Collins (1985, 1994), Akagawa-Matsushita et al. (1992) and Nishijima et al. (1997) and analysed their fatty acid compositions using the protocol described by Bowman (2001) and Fay \& Richli (1991) under experimental and instrumental conditions described previously (Zhao et al., 2005). Strains HAW$\mathrm{EB}^{\mathrm{T}}{ }^{\mathrm{T}}$ and HAW-EB5 ${ }^{\mathrm{T}}$ contained ubiquinones (Q-7, Q-8) and menaquinones (MK-7 and/or MMK-7) (details in the species descriptions) that are commonly found in Shewanella (Bowman, 2005). Strain HAW-EB2 ${ }^{\mathrm{T}}$ appeared not to contain MMK-7, which was found in S. sediminis DSM $17055^{\mathrm{T}}$ (Zhao et al., 2005) and HAW-EB5 ${ }^{\mathrm{T}}$. The major fatty acids of strains $\mathrm{HAW}-\mathrm{EB}^{\mathrm{T}}$ and $\mathrm{HAW}-\mathrm{EB} 2^{\mathrm{T}}$ were palmitic acid $\left(\mathrm{C}_{16: 0} ; 19 \%\right)$, myristic acid $\left(\mathrm{C}_{14: 0} ; 4-\right.$ $12 \%)$, palmitoleic acid $\left(\mathrm{C}_{16: 1} \omega 7 ; 34-39 \%\right)$ and branched acids iso- $\mathrm{C}_{13: 0}(3-5 \%)$ and iso- $\mathrm{C}_{15: 0}(8-11 \%)$, similar to $S$. woodyi, S. hanedai, S. benthica, S. violacea and S. gelidimarina (see Supplementary Table S1 in IJSEM Online). Like S. gelidimarina, S. benthica, S. violacea and S. hanedai, the two strains produced eicosapentaenoic acid $\left(\mathrm{C}_{20: 5} \omega 3\right.$, EPA; 4-6\%).

The two strains were also tested for their tolerance to $\mathrm{NaCl}$ on Brewer anaerobic agar containing 0.5, 1.5, 2.0, 2.5, 3.0, 


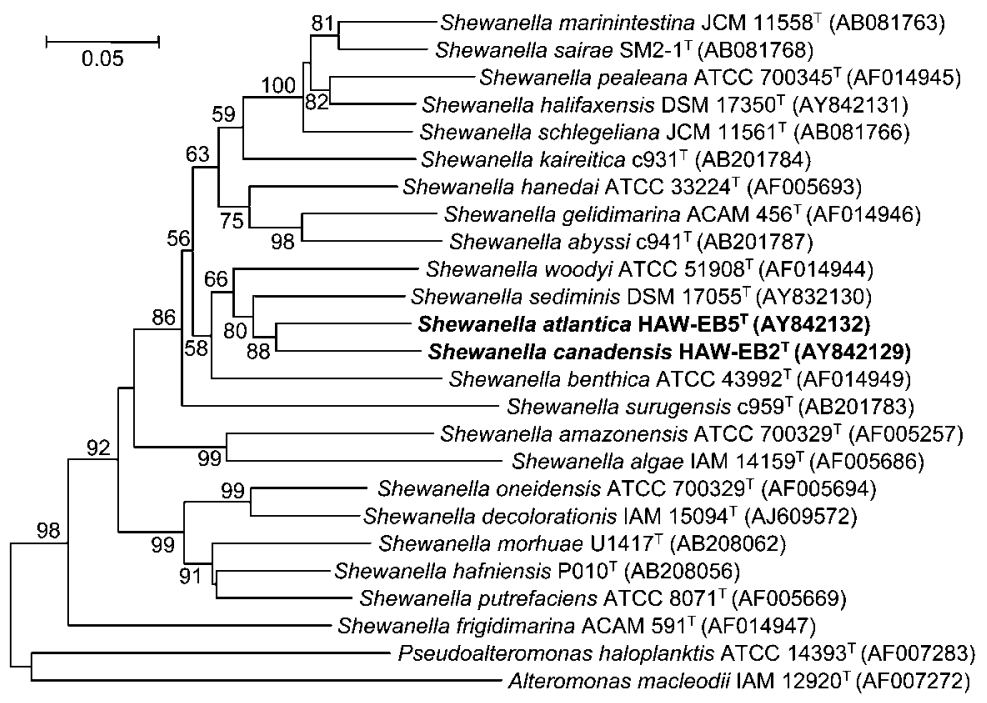

Fig. 3. Phylogenetic tree based on gyrB sequences of strains $\mathrm{HAW}-\mathrm{EB} 2^{\top}$ and HAW$\mathrm{EB}^{\top}{ }^{\top}$ and type strains of Shewanella species. The tree was generated based on pairwise nucleotide distances as described in the text. Bar, 5 substitutions per 100 nucleotide positions. Numbers beside nodes are statistical bootstrap values (values lower than $50 \%$ are not shown).

4.0, 6.0 or $8.0 \%(\mathrm{w} / \mathrm{v}) \mathrm{NaCl}$ (aerobic growth conditions). Growth in the absence of $\mathrm{Na}^{+}$was tested in a $\mathrm{Na}^{+}$-free agar that contained $0.3 \%$ Bacto beef extract and $0.5 \%$ Bacto peptone. The two strains required a minimum of $1 \%$ $(w / v) \mathrm{NaCl}$ for growth and both showed optimal growth in the presence of $1.5-3 \% \mathrm{NaCl}$, similar to many species of Shewanella. Strain HAW-EB5 ${ }^{\mathrm{T}}$ appeared to be more halotolerant than $\mathrm{HAW}-\mathrm{EB} 2^{\mathrm{T}}$ because, at $4 \%(\mathrm{w} / \mathrm{v}) \mathrm{NaCl}$, strain $\mathrm{HAW}-\mathrm{EB} 5^{\mathrm{T}}$ showed good growth whereas strain $\mathrm{HAW}-\mathrm{EB} 2^{\mathrm{T}}$ did not grow.

To compare the phenotypic properties of strains HAW$\mathrm{EB} 2^{\mathrm{T}}$ and $\mathrm{HAW}-\mathrm{EB} 5^{\mathrm{T}}$ with known species of Shewanella further, we used previously described protocols (Bowman, 2001; Smibert \& Krieg, 1994) to test the following biochemical and physiological properties: spore formation, $\mathrm{H}_{2} \mathrm{~S}$ formation from thiosulfate, acid production from various sugars ( $1 \% \mathrm{w} / \mathrm{v}$ in Leifson modified O-F medium), activities of catalase, oxidase and DNase (in BBL DNA agar, supplemented with $4 \% \mathrm{w} / \mathrm{v}$ sea salts; Becton Dickinson), hydrolysis of casein ( $50 \% \mathrm{w} / \mathrm{v}$ skimmed milk), gelatin $(1 \%$, w/v), Tweens 20, 40 and $80(1 \% \mathrm{w} / \mathrm{v})$, olive oil $(1 \% \mathrm{w} / \mathrm{v})$, lecithin $(5 \% \mathrm{w} / \mathrm{v}$ egg yolk), pure chitin $(0.3 \% \mathrm{w} / \mathrm{v})$, alginate $(1 \% \mathrm{w} / \mathrm{v})$ and starch $(1 \% \mathrm{w} / \mathrm{v})$ using marine broth 2216 as a basal medium. Aerobic utilization of substrates $(0.1 \% \mathrm{w} / \mathrm{v})$ as sole carbon and energy sources was tested in basic marine salts medium ( $\mathrm{pH}$ 7.0) containing $0.1 \%(\mathrm{w} / \mathrm{v}) \mathrm{NH}_{4} \mathrm{Cl}$ as the nitrogen source (Zhao et al., 2005). Reduction of electron acceptors was tested on Brewer anaerobic agar supplemented with $2 \%(\mathrm{w} / \mathrm{v}) \mathrm{NaCl}$ (in anaerobic jars) and one of the following compounds: manganese dioxide $\left(\mathrm{MnO}_{2}, 40 \mathrm{mM}\right)$, ferric citrate (40 mM), amorphous iron oxide (FeOOH, $40 \mathrm{mM})$, TMAO $(5 \mathrm{mM})$, nitrate $(5 \mathrm{mM})$, nitrite $(5 \mathrm{mM})$ and elemental sulfur $(40 \mathrm{mM})$. Clear zones around colonies were used to indicate reduction of $\mathrm{Fe}(\mathrm{III}), \mathrm{Mn}(\mathrm{IV})$ and sulfur (Myers \& Nealson, 1988). Enhanced growth of strains in the presence of electron acceptors was used as an indicator of dissimilatory reduction. Bacterial growth on agar was estimated by multiplying the average area of colonies and the total number of colony-forming units (Zhao et al., 2005). Additional enzyme activities and utilization of substrates were tested by API Rapid 20E and ID32A (bioMérieux) test kits and GN2 microplates (Biolog) (using a cell suspension in sea-salts medium with an $\mathrm{OD}_{600}$ of $0.9 ; 10$ days incubation). Results were determined by colour change as instructed by the manufacturers: no colour change, negative; faint colour change,

Table 1. Similarity of $16 \mathrm{~S}$ rRNA and $g y r B$ gene sequences and total genomic DNA-DNA relatedness between the novel isolates and type strains of related species of Shewanella

Values above the diagonal are percentages of $16 \mathrm{~S} \mathrm{rRNA} / \mathrm{gyrB}$ gene sequence similarity; values below the diagonal are percentages of DNA-DNA relatedness. ND, Not determined.

\begin{tabular}{|c|c|c|c|c|c|}
\hline Strain & 1 & 2 & 3 & 4 & 5 \\
\hline 1. HAW-EB2 ${ }^{\mathrm{T}}$ & - & $98.9 / 87.6$ & $99.5 / 85.5$ & $97.8 / 83.0$ & $97.8 / 83.0$ \\
\hline 2. $\mathrm{HAW}-\mathrm{EB} 5^{\mathrm{T}}$ & 22 & - & $98.6 / 86.5$ & $97.8 / 84.5$ & $97.1 / 80.6$ \\
\hline 3. S. sediminis $\mathrm{HAW}-\mathrm{EB} 3^{\mathrm{T}}$ & 41 & 40 & - & ND & ND \\
\hline 4. S. woodyi ATCC $51908^{\mathrm{T}}$ & 9 & 14 & ND & - & ND \\
\hline 5. S. hanedai ATCC $33224^{\mathrm{T}}$ & 20 & 15 & $\mathrm{ND}$ & ND & - \\
\hline
\end{tabular}


negative for API Rapid 20E and ID32A and weakly positive for Biolog tests; strong colour change, positive. For comparison, S. sediminis HAW-EB3 ${ }^{\mathrm{T}}$, S. woodyi ATCC $51908^{\mathrm{T}}$, S. hanedai ATCC $33224^{\mathrm{T}}$ and S. benthica ATCC 43991 were tested for reduction of $\mathrm{MnO}_{2}, \mathrm{H}_{2} \mathrm{~S}$ production from thiosulfate, activity of catalase and other enzymes using ID32A and metabolism of Biolog (GN2) substrates under the conditions used for strains $\mathrm{HAW}-\mathrm{EB} 2^{\mathrm{T}}$ and HAW-EB5 ${ }^{\mathrm{T}}$. All of the above physiological properties were tested in triplicate at $10{ }^{\circ} \mathrm{C}$ unless noted otherwise.

The two strains, like all species of Shewanella, were positive for oxidase activity and for reduction of TMAO and nitrate. Cluster analyses of phenotypic properties, conducted as described previously (Zhao et al., 2005), of the two strains and all species of Shewanella showed that strains HAW-EB5 ${ }^{\mathrm{T}}$ and HAW-EB2 ${ }^{\mathrm{T}}$ were close to the intermediate-sea species $S$. sediminis and S. woodyi, consistent with the earlier observation made from 16S rRNA and $g y r B$ gene sequencing. Like S. sediminis, S. woodyi and S. benthica, the two strains reduced $\mathrm{MnO}_{2}$, a common sediment component in the marine environment. As shown in Table 2, strains HAW-EB5 ${ }^{\mathrm{T}}$ and HAW-EB2 ${ }^{\mathrm{T}}$ exhibited significant differences from each other and from related species ( $S$. sediminis, S. woodyi, S. hanedai, S. violacea and $S$. benthica) in several phenotypic properties such as bioluminescence, requirements for temperature, $\mathrm{NaCl}$ and pressure and metabolism of certain sugars and acids.

All of the genetic (Figs 2 and 3; Table 1), chemotaxonomic (Supplementary Table S1) and phenotypic (Table 2) data presented above demonstrate that strains $\mathrm{HAW}-\mathrm{EB} 2^{\mathrm{T}}$ and HAW-EB $5^{\mathrm{T}}$ represent novel species of Shewanella, named Shewanella canadensis sp. nov. and Shewanella atlantica sp. nov., respectively.

\section{Description of Shewanella canadensis sp. nov.}

Shewanella canadensis (ca.na.den'sis. N.L. fem. adj. canadensis from Canada, the country nearest to the sediment sampling site, Emerald Basin, where the type strain was isolated).

Cells are Gram-negative, non-spore-forming, straight or slightly curved rods, $1.5-3.5 \mu \mathrm{m}$ long and $0.65-0.75 \mu \mathrm{m}$ in diameter. Motile by a single flagellum in a polar position. Biomass is dark orange or slightly pinkish and nonbioluminescent. Psychrophilic growth at temperatures of $4-25{ }^{\circ} \mathrm{C}$ (inclusive; optimum growth at $10{ }^{\circ} \mathrm{C}$ ); no growth at $30{ }^{\circ} \mathrm{C}$. Able to grow at $1-3 \%(\mathrm{w} / \mathrm{v}) \mathrm{NaCl}$. Requires at least $1 \%(\mathrm{w} / \mathrm{v}) \mathrm{NaCl}$ for growth. Little growth at $4 \%(\mathrm{w} / \mathrm{v})$ $\mathrm{NaCl}$ (biomass obtained at $4 \% \mathrm{NaCl}$ is $3 \%$ of optimum). No growth at $6 \%(\mathrm{w} / \mathrm{v}) \mathrm{NaCl}$. TMAO, $\mathrm{MnO}_{2}$, nitrate, nitrite and hexahydro-1,3,5-trinitro-1,3,5-triazine (RDX) are reduced. Negative for reduction of $\mathrm{Fe}$ (III) and elemental sulfur. Weak production of $\mathrm{H}_{2} \mathrm{~S}$ from thiosulfide. Positive for oxidase, nitroreductase (reduction of nitrate, nitrite and nitro group of RDX), caseinase, chitinase, gelatinase and DNase. Weakly positive for catalase. Negative for alginase, amylase, agarase and lipase (hydrolysis of Tweens 20, 40 and 80). In API ID32A and API 20E tests, positive for urease, ornithine decarboxylase, lysine decarboxylase, $N$-acetyl- $\beta$-D-glucosaminidase, $\beta$-galactosidase, $\beta$-galactosidase-6-phosphate, alkaline phosphatase, arginine arylamidase, proline arylamidase, leucine glycine arylamidase, tyrosine arylamidase, alanine arylamidase, leucine arylamidase and glutamyl glutamic acid arylamidase. In Biolog GN2 microplate tests, positive for metabolism of Tween $80, N$-acetyl-D-glucosamine, acetate, $\beta$-hydroxybutyrate, DL-lactate, propionate, succinate, L-alanine, L-serine, Lthreonine, L-leucine, L-aspartate, L-proline, L-alanyl glycine, glycyl L-aspartate, glycyl L-glutamate, inosine, uridine and thymidine; weakly positive for Tween 40 and methylpyruvate. $N$-Acetyl-D-glucosamine is only oxidized to acid under oxic conditions. Galactose, lactose, fructose, sucrose, mannose and glucose are not oxidized or fermented to acids. Tween 40 , malate, succinate, valerate, peptone and yeast extract are used as sole carbon and energy sources. Fatty acids $\mathrm{C}_{12: 0} 3-\mathrm{OH}(1 \%)$, iso- $\mathrm{C}_{13: 0}(5 \%), \mathrm{C}_{14: 0}$ $(12 \%), \mathrm{C}_{14: 1}(1 \%), \mathrm{C}_{15: 0}(1 \%)$, iso- $\mathrm{C}_{15: 0}(8 \%), \mathrm{C}_{16: 0}$ (19\%), $C_{16: 1} \omega 7(39 \%), C_{18: 0}(1 \%), C_{18: 1} \omega 7(4 \%), C_{20: 1}$ $(1 \%), \mathrm{C}_{20: 5} \omega 3(4 \%)$ and $\mathrm{C}_{21: 0}(1 \%)$ are produced. Quinone composition is Q-7 (39.1\%), Q-8 (15.9\%), MK-7 (44.9\%) and MMK-7 (trace). The molar DNA $\mathrm{G}+\mathrm{C}$ content is $46.4 \pm 0.3 \mathrm{~mol} \%$.

The type strain is HAW-EB2 ${ }^{\mathrm{T}}\left(=\mathrm{NCIMB} 14238^{\mathrm{T}}=\mathrm{CCUG}\right.$ $54553^{\mathrm{T}}$ ).

\section{Description of Shewanella atlantica sp. nov.}

Shewanella atlantica (at.lan'ti.ca. L. fem. adj. atlantica of the Atlantic Ocean, where the type strain was isolated).

Cells are Gram-negative, non-spore-forming, straight or slightly curved rods, $2-5 \mu \mathrm{m}$ long and $0.5-0.6 \mu \mathrm{m}$ in diameter. Motile by a single flagellum in a polar or subpolar position. Biomass is slightly pinkish and nonbioluminescent. Psychrophilic growth at temperatures of $4-25{ }^{\circ} \mathrm{C}$ (optimum growth at $10{ }^{\circ} \mathrm{C}$ ); no growth at $30{ }^{\circ} \mathrm{C}$. $\mathrm{Na}^{+}$is required for growth; grows at $1-4 \%(\mathrm{w} / \mathrm{v}) \mathrm{NaCl}$ (growth at $4 \% \mathrm{NaCl}$ is $32 \%$ of optimum). No growth at $6 \% \mathrm{NaCl}$. TMAO, $\mathrm{MnO}_{2}$, nitrate, nitrite, thiosulfate and RDX are reduced. $\mathrm{H}_{2} \mathrm{~S}$ is produced from thiosulfate. Negative for reduction of $\mathrm{Fe}$ (III) and elemental sulfur. Positive for oxidase, nitroreductase, chitinase, lipase (hydrolysis of Tweens 20,40 and 80) and DNase. Weakly positive for catalase and caseinase. Negative for gelatinase, alginase and amylase. In API ID32A and API 20E tests, positive for urease, ornithine decarboxylase, lysine decarboxylase, $N$-acetyl- $\beta$-D-glucosaminidase, $\beta$-galactosidase, glutamate decarboxylase, $\beta$-galactosidase-6-phosphate, alkaline phosphatase, arginine arylamidase, proline arylamidase, leucine glycine arylamidase, alanine arylamidase, glycine arylamidase, leucine arylamidase, serine arylamidase and glutamyl glutamic acid arylamidase. In Biolog GN2 microplate tests, positive for metabolism of Tweens 40 and $80, N$-acetyl-D-glucosamine, acetate, lactate, 
Table 2. Characteristics that differentiate strains $\mathrm{HAW}-\mathrm{EB} 2^{\top}$ and $\mathrm{HAW}-\mathrm{EB} 5^{\top}$ and related species of Shewanella

Unless otherwise noted, properties of S. woodyi, S. hanedai and S. benthica were obtained in the present study using strains ATCC 51908 ${ }^{\mathrm{T}}$, ATCC $33224^{\mathrm{T}}$ and ATCC $43991^{\mathrm{T}}$, respectively, and under the same experimental conditions used for HAW-EB2 ${ }^{\mathrm{T}}$ and HAW-EB5 ${ }^{\mathrm{T}}$. Other sources of data for reference species are indicated. +, Positive; -, negative; w, weak; ND, no data. In the present study, all strains were found to be positive for reduction of $\mathrm{MnO}_{2}$, activities of $\mathrm{N}$-acetyl- $\beta$-D-glucosaminidase, alkaline phosphatase, arginine arylamidase, proline arylamidase, leucine glycine arylamidase, alanine arylamidase, glutamyl glutamic acid arylamidase and arabinosidase (the latter was weak for S. benthica ATCC $43991^{\mathrm{T}}$ ) and metabolism of Tweens 40 and 80, DL-lactate, L-alanine, L-serine, L-threonine, glycyl L-aspartate, glycyl L-glutamate, L-proline, L-leucine, L-alanyl glycine, inosine, uridine and thymidine. All strains were negative for metabolism of other substrates of GN2 microplates and activities of enzymes tested by API Rapid ID 32A.

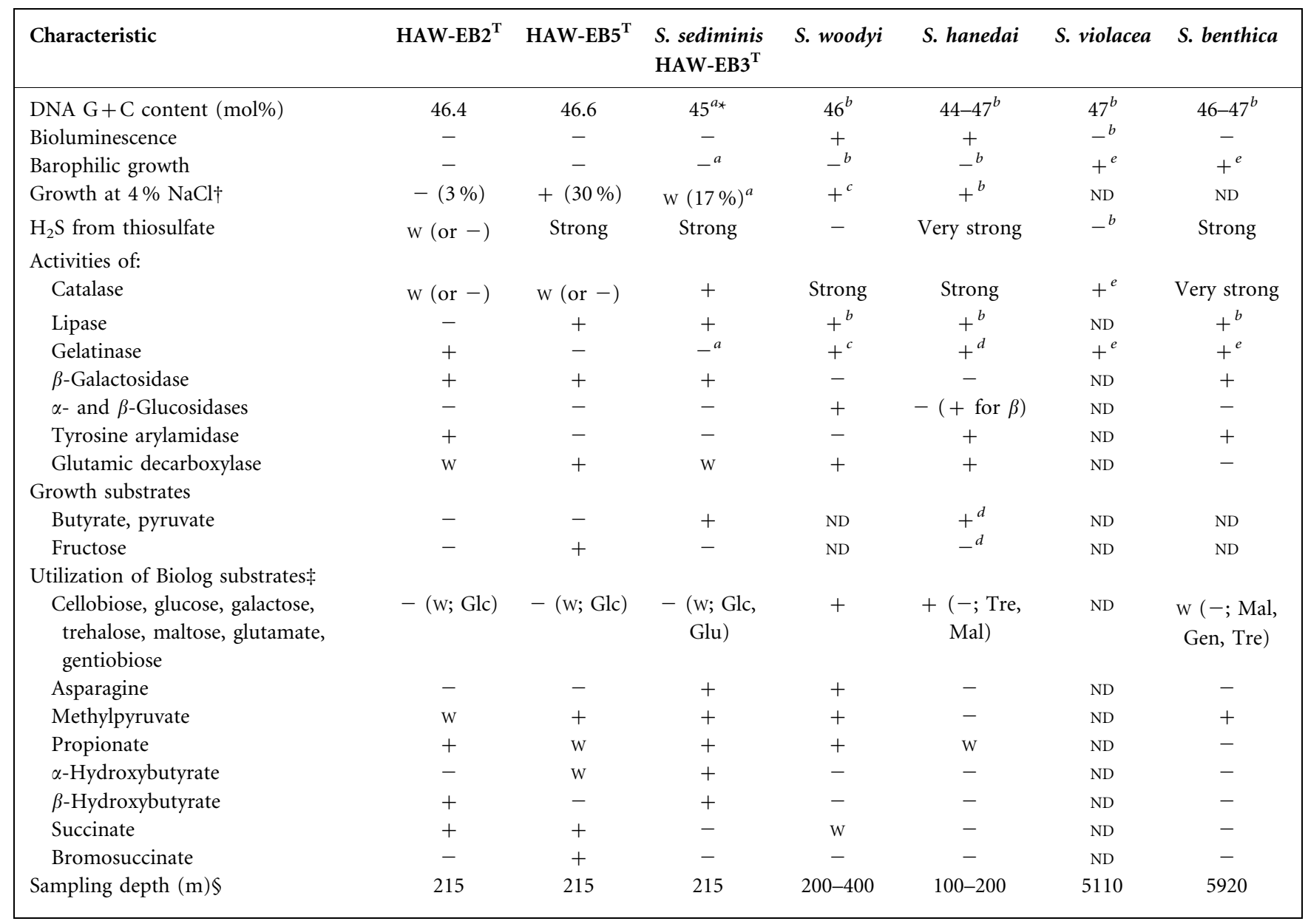

${ }^{\star}$ Data taken from the following studies: $a$, Zhao et al. (2005); b, Bowman (2005); c, Makemson et al. (1997); d, Jensen et al. (1980); e, Nogi et al. (1998).

$\dagger$ Relative amount of biomass obtained at $4 \% \mathrm{NaCl}$ shown in parentheses in comparison with that obtained at $2 \% \mathrm{NaCl}$.

¥Gen, Gentiobiose; Glc, glucose; Glu, glutamate; Mal, maltose; Tre, trehalose.

$\S$ Sampling sites: strains HAW-EB2 ${ }^{\mathrm{T}}, \mathrm{HAW}-\mathrm{EB}^{\mathrm{T}}{ }^{\text {and }}$ S. sediminis HAW-EB3 ${ }^{\mathrm{T}}$, Emerald Basin sediment, Atlantic Ocean off Halifax; S. woodyi strains, detritus, squid ink and seawater of Alboran Sea; S. hanedai strains, sediment and water of Antarctic, Arctic and Pacific Oceans; S. violacea strains, sediment of Ryukyu Trench; S. benthica ATCC $43991^{\mathrm{T}}$, intestine of Scopelocheirus shellengi, Puerto Rico Trench.

methylpyruvate, L-alanine, L-aspartate, L-serine, L-leucine, L-proline, L-threonine, L-alanyl glycine, glycyl L-aspartate, glycyl L-glutamate, inosine, uridine and thymidine; weakly positive for glycogen, $\alpha$-hydroxybutyrate, $\alpha$-ketobutyrate, succinate and bromosuccinate. Acetate, malate, valerate, fructose, peptone and yeast extract are used as sole carbon and energy sources for growth. $N$-Acetyl-D-glucosamine is oxidized weakly and fermented to acid. Fructose and sucrose are fermented very slowly to acids. Galactose, lactose, mannose and glucose are not oxidized or fermented to acids. Fatty acids $\mathrm{C}_{12: 0} 3-\mathrm{OH}(3 \%)$, iso$\mathrm{C}_{13: 0}(3 \%), \mathrm{C}_{13: 0} 3-\mathrm{OH}(5 \%), \mathrm{C}_{14: 0}(4 \%), \mathrm{C}_{14: 1}(1 \%)$, anteiso- $\mathrm{C}_{15: 0}(1 \%), \mathrm{C}_{15: 0}(1 \%)$, iso- $\mathrm{C}_{15: 0}(11 \%), \mathrm{C}_{16: 0}$ (19\%), $\mathrm{C}_{16: 1} \omega 7$ (34\%), iso- $\mathrm{C}_{17: 0}(1 \%), \mathrm{C}_{18: 0}(2 \%)$, $\mathrm{C}_{18: 1} \omega 7(7 \%), \mathrm{C}_{20: 1}(1 \%), \mathrm{C}_{20: 5} \omega 3(6 \%)$ and $\mathrm{C}_{21: 0}(1 \%)$ are produced. Quinone composition is Q-7 (13.5\%), Q-8 
(10.3\%), MK-7 (67.9\%) and MMK-7 (8.3\%). The molar DNA G $+\mathrm{C}$ content is $46.4 \pm 0.1 \mathrm{~mol} \%$.

The type strain is HAW-EB5 ${ }^{\mathrm{T}}\left(=\mathrm{NCIMB} 14239^{\mathrm{T}}=\mathrm{CCUG}\right.$ $\left.54554^{\mathrm{T}}\right)$.

\section{Acknowledgements}

Funding for this research was provided by the Office of Naval Research (ONR, US Navy) (award N000140310269, grant N000140610251) and the DRDC, DND, Canada. The authors would like to thank D. Faucher (Defense Research and Development Canada, Valcartier, Quebec, Canada) and K. Penny (Canadian Navy) for sampling sediment. Transmission and scanning electron micrographs were prepared by C. Leggiadro and D. O'Neil (Institute of Marine Biosciences, National Research Council, Halifax, Nova Scotia, Canada). Spectral analyses of bacterial quinones by HPLC-UV (diode array) and LC-MS were conducted by Louise Paquet and Annamaria Halasz, respectively. Fatty acid analysis was conducted by Chantale Beaulieu.

\section{References}

Akagawa-Matsushita, M., Itoh, T., Katayama, Y., Kuraishi, H. \& Yamasato, K. (1992). Isoprenoid quinone composition of some marine Alteromonas, Marinomonas, Deleya, Pseudomonas and Shewanella species. J Gen Microbiol 138, 2275-2281.

Bowman, J. P. (2001). Methods for psychrophilic bacteria. Methods Microbiol 30, 591-615.

Bowman, J. P. (2005). Genus XIII. Shewanella MacDonell and Colwell 1986, 355 ${ }^{\mathrm{VP}}$. In Bergey's Manual of Systematic Bacteriology, 2nd edn, vol. 2, part B, pp. 480-491. Edited by D. J. Brenner, N. R. Krieg, J. T. Staley \& G. M. Garrity. New York: Springer-Verlag.

Bowman, J. P., McCammon, S. A., Nichols, D. S., Skerratt, J. H., Rea, S. M., Nichols, P. D. \& McMeekin, T. A. (1997). Shewanella gelidimarina sp. nov. and Shewanella frigidimarina sp. nov., novel Antarctic species with the ability to produce eicosapentaenoic acid (20:5 $\omega 3)$ and grow anaerobically by dissimilatory $\mathrm{Fe}(\mathrm{III})$ reduction. Int J Syst Bacteriol 47, 1040-1047.

Bowman, J. P., McCammon, S. A., Lewis, T., Skerratt, J. H., Nichols, D. S. \& McMeekin, T. A. (1998). Psychroflexus torquis gen. nov., sp. nov., a psychrophilic species from Antarctic sea ice, and reclassification of Flavobacterium gondwanense (Dobson et al. 1993) as Psychroflexus gondwanense gen. nov., comb. nov. Microbiology 144, 1601-1609.

Collins, M. D. (1985). Analysis of isoprenoid quinones. Methods Microbiol 18, 329-366.

Collins, M. D. (1994). Isoprenoid quinones. In Chemical Methods in Prokaryotic Systematics, pp. 265-309. Edited by M. Goodfellow \& A. G. O’Donnell. Chichester: Wiley.

Deming, J. W., Hada, H., Colwell, R. R., Luehrsen, K. R. \& Fox, G. E. (1984). The ribonucleotide sequence of $5 S$ rRNA from two strains of deep-sea barophilic bacteria. J Gen Microbiol 130, 1911-1920.

Fay, L. \& Richli, U. (1991). Location of double bonds in polyunsaturated fatty acids by gas chromatography-mass spectrometry after 4,4-dimethyloxazoline derivatization. J Chromatogr 541, 89-98.

Jensen, M. J., Tebo, B. M., Baumann, P., Mandel, M. \& Nealson, K. H. (1980). Characterization of Alteromonas hanedai (sp. nov.), a nonfermentative luminous species of marine origin. Curr Microbiol 3, 311-315.

Johnson, J. L. (1985a). Determination of DNA base composition. Methods Microbiol 18, 23-24.
Johnson, J. L. (1985b). DNA reassociation and RNA hybridisation of bacterial nucleic acids. Methods Microbiol 18, 33-74.

Johnson, J. L. (1994). Similarity analysis of DNAs. In Methods for General and Molecular Bacteriology, pp. 655-682. Edited by P. Gerhardt, R. G. E. Murray, W. A. Wood \& N. R. Krieg. Washington, DC: American Society for Microbiology.

Kato, C. \& Nogi, Y. (2001). Correlation between phylogenetic structure and function: examples from deep sea Shewanella. FEMS Microbiol Ecol 35, 223-230.

Kimura, M. (1980). A simple method for estimating evolutionary rates of base substitutions through comparative studies of nucleotide sequences. J Mol Evol 16, 111-120.

Kumar, S., Tamura, K. \& Nei, M. (2004). MEGA3: integrated software for molecular evolutionary genetics analysis and sequence alignment. Brief Bioinform 5, 150-163.

Makemson, J. C., Fulayfil, N. R., Landry, W., Van Ert, L. M., Wimpee, C. F., Widder, E. A. \& Case, J. F. (1997). Shewanella woodyi sp. nov., an exclusively respiratory luminous bacterium isolated from the Alboran Sea. Int J Syst Bacteriol 47, 1034-1039.

Myers, C. R. \& Nealson, K. H. (1988). Bacterial manganese reduction and growth with manganese oxide as the sole electron acceptor. Science 240, 1319-1321.

Nishijima, M., Araki-Sakai, M. \& Sano, H. (1997). Identification of isoprenoid quinones by frit-FAB liquid chromatography-mass spectrometry for the chemotaxonomy of microorganisms. J Microbiol Methods 28, 113-122.

Nogi, Y., Kato, C. \& Horikoshi, K. (1998). Taxonomic studies of deepsea barophilic Shewanella strains and description of Shewanella violacea sp. nov. Arch Microbiol 170, 331-338.

Park, D. H. \& Zeikus, J. (2002). Impact of electrode composition on electricity generation in a single-compartment fuel cell using Shewanella putrefaciens. Appl Microbiol Biotechnol 59, 58-61.

Petrovskis, E. A., Vogel, T. M. \& Adriaens, P. (1994). Effects of electron acceptors and donors on transformation of tetrachloromethane by Shewanella putrefaciens MR-1. FEMS Microbiol Lett 121, 357-364.

Ringeisen, B. R., Henderson, E., Wu, P. K., Pietron, J., Ray, R., Little, B., Biffinger, J. C. \& Jones-Meehan, J. M. (2006). High power density from a miniature microbial fuel cell using Shewanella oneidensis DSP10. Environ Sci Technol 40, 2629-2634.

Roh, Y., Gao, H., Vali, H., Kennedy, D. W., Yang, Z. K., Gao, W., Dohnalkova, A. C., Stapleton, R. D., Moon, J. W. \& other authors (2006). Metal reduction and iron biomineralization by a psychrotolerant Fe(III)-reducing bacterium, Shewanella sp. strain PV-4. Appl Environ Microbiol 72, 3236-3244.

Russell, N. J. \& Nichols, D. S. (1999). Polyunsaturated fatty acids in marine bacteria - a dogma rewritten. Microbiology 145, 767-779.

Saitou, N. \& Nei, M. (1987). The neighbor-joining method: a new method for reconstructing phylogenetic trees. Mol Biol Evol 4, 406-425.

Sambrook, J. \& Russell, D. W. (2001). Molecular Cloning: a Laboratory Manual, 3rd edn. Cold Spring Harbor, NY: Cold Spring Harbor Laboratory.

Smibert, R. M. \& Krieg, N. R. (1994). Phenotypic characterization. In Methods for General and Molecular Bacteriology, pp. 607-654. Edited by P. Gerhardt, R. G. E. Murray, W. A. Wood \& N. R. Krieg. Washington, DC: American Society for Microbiology.

Stackebrandt, E. \& Goebel, B. M. (1994). Taxonomic note: a place for DNA-DNA reassociation and $16 \mathrm{~S}$ rRNA sequence analysis in the present species definition in bacteriology. Int J Syst Bacteriol 44, 846-849. 
Venkateswaran, K., Moser, D. P., Dollhopf, M. E., Lies, D. P., Saffarini, D. A., MacGregor, B. J., Ringelberg, D. B., White, D. C., Nishijima, M. \& other authors (1999). Polyphasic taxonomy of the genus Shewanella and description of Shewanella oneidensis sp. nov. Int J Syst Bacteriol 49, 705-724.

Wayne, L. G., Brenner, D. J., Colwell, R. R., Grimont, P. A. D., Kandler, O., Krichevsky, M. I., Moore, L. H., Moore, W. E. C., Murray, R. G. E. \& other authors (1987). International Committee on Systematic Bacteriology. Report of the ad hoc committee on reconciliation of approaches to bacterial systematics. Int J Syst Bacteriol 37, 463-464.

Zhao, J.-S., Spain, J., Thiboutot, S., Ampleman, G., Greer, C. \& Hawari, J. (2004a). Phylogeny of cyclic nitramine-degrading psychrophilic bacteria in marine sediment and their potential role in the natural attenuation of explosives. FEMS Microbiol Ecol 49, 349-357.

Zhao, J.-S., Greer, C. W., Thiboutot, S., Ampleman, G. \& Hawari, J. (2004b). Biodegradation of nitramine explosives hexahydro-1,3,5trinitro-1,3,5-triazine and octahydro-1,3,5,7-tetranitro-1,3,5,7-tetrazocine in cold marine sediment under anaerobic and oligotrophic conditions. Can J Microbiol 50, 91-96.

Zhao, J.-S., Manno, D., Beaulieu, C., Paquet, L. \& Hawari, J. (2005). Shewanella sediminis sp. nov, a novel $\mathrm{Na}^{+}$-requiring and hexahydro1,3,5-trinitro-1,3,5-triazine-degrading bacterium from marine sediment. Int J Syst Evol Microbiol 55, 1511-1520.

Zhao, J.-S., Manno, D. \& Hawari, J. (2006). Shewanella halifaxensis sp. nov, a novel obligately respiratory and denitrifying psychrophile. Int $J$ Syst Evol Microbiol 56, 205-212. 